\title{
Planned redesign of beehive coke ovens for pollution control and power generation
}

Fossil fuel based thermal power or ovens not only exude greenhouse gases and pollutants but transfer enormous amount of waste heat up in air. Heat gets enveloped in the stratosphere and circulate around the earth; escalating global warming. France, Czech Republic, Slovakia, Austria, Andorra, Luxembourg, Poland and Germany made it the hottest June on record in 2019. Around 50 coke ovens around Dhanbad are losing and facing closure, with fate of employees doomed. Jharkhand State Pollution Control Board, Dhanbad had been issuing letters to the small-scale refractory and beehive hard coke-ovens to bring down stack gas emissions to below $150 \mathrm{mg} / \mathrm{Nm}^{3}$ of suspended particulate matter (SPM), equivalent to the standards of large thermal power plants, deploying electrostatic precipitators (ESP). Some locally made pollution control devices were deployed, but these reduced the chimney draft and coking time increased. Installation of wet scrubbing methods would not be economic and slow down production. With experience as the Manager of a by-product coke oven, the chimney detour method with mechanical exhauster suggested for beehive coke oven. Proposed design not only can generate power, but also trap pollutants by a kind of wet scrubbing and produce byproducts like coal tar. Various associations of small-scale hard coke ovens and refractory industries had approached The Institution of Engineers (India), Dhanbad Local Centre. In this paper, the authors briefly present how waste heat can be converted to power, while absorbing pollutants in hydraulic main in the unique chimney detour method and producing coal tar, exuding clean gas.

Keywords: Flue gases; coke ovens; hydraulic main; chimney detour method; thermodynamics; converting pollutants.

\subsection{Introduction}

$\mathrm{N}$ on-recovery coke plants are originally referred to as beehive types, and in this project attempt has been made to convert to recovery type in small such ovens. The second law of thermodynamics states that waste

Messrs. Binay Kumar Samanta, Department of Mining Engineering and Manish Kumar Jain, Department of Environment Science and Engineering, Indian Institute of Technology (Indian School of Mines), Dhanbad 826004. Email: iitism.bks@outlook.com, manish@iitism.ac.in heat must be produced when converting a temperature difference into mechanical energy. India loses USD 68 billion, or about Rs 4,14,800 crores of its gross domestic product due to electricity shortage, as per FICCI report on Power Transmission. There is urgent need of generating power at small scale for additional revenue, while converting pollutants to useful products. Some energy is consumed and rest is dissipated into the atmosphere as heat, with great concern across the world (Guang J. Zhang, Ming Cai and Aixue Hu 2013). The future of coal-based thermal power, identified as the biggest emitter of greenhouse gases and heat is threatened. Power generation with waste heat and absorption of GHG and converting pollutants can be panacea for coal utilization industry.

Many types of new technologies (Colak I, Sagiroglu S, Fulli $\mathrm{G}$ et al 2016) for minimizing $\mathrm{CO}_{2}$ emissions are evolving like carbon sequestration, storage, $\mathrm{CO}_{2}$ capture etc. In this method raw coal feed of roughly $20 \% \mathrm{VM}$, coal gas available would be $200 \times 36=7200 \mathrm{~m}^{3}$ per day $=300 \mathrm{~m}^{3}$ per hour and at chimney temperature around $900^{\circ} \mathrm{C}$. Even small hard coke ovens can generate $500-1000 \mathrm{~kW}$ power, for their ancillary industries or sell to State Electricity Board grid. Waste heat dissipation in air should be minimized as up to $3 \mathrm{MW}$ generation is permitted by Indian Electricity Rules 2003.

\subsection{Investigations}

According to Air (pollution and control) Act and Rules 1981, permissible limits of air pollution, SPM (suspended particulate matter) in micro-gm/ $\mathrm{m}^{3}$ and gases in ppm (parts per million), as followed in environmental monitoring have to be followed. Industry \& Commerce Association, Dhanbad allowed projects and environment consultants for preliminary inspection of the Jealgora-Gobindpur coke oven plant of M/S Industrial Engineering Co. Discussions were held at site with plant officials and it was found amenable for the project. This was discussed with Environment Department of ISM (Venkatesh A., Singh G, Reddy DV and Jain MK 2010) and confirmation for joint inspection was received. Joint inspection was made of the Jealgora-Gobindpur plant with ISM professors and provisional layout of different components like temporary chimney, exhaust gas boiler, steam turbine, generator, control panel, hydraulic main, exhauster, coal-tar and ammonia liquor 